\title{
TRANSPORT AS A PUBLIC GOOD
}

\section{TOMASZ KWARCIŃSKI}

University of Szczecin, Faculty of Management and Economics of Services, POLAND

e-mail: tomasz.kwarcinski@wzieu.pl

RECEIVED
ACCEPTED
JEL
CLASSIFICATION

KEYWORDS

ABSTRACT
18 January 2018

2 September 2018

H41, R42

public good, transport, transport infrastructure, passenger transport services

This article attempts to apply the theory of public goods to the transport sphere. The characteristics and classifications of specific types of public goods, i.e. pure goods, club goods, and common goods, are presented. In this respect, attention is paid to spatial, economic, social, and environmental criteria. The role of public goods in correcting the failure of market mechanisms should be emphasized. Defined through the prism of transport services, the lack of proper transport accessibility may be an example of the failure of market mechanisms. This is the case when the demand for transport services is low, which results in limited offers from market participants. The role of the central and/or local government is to correct this situation by assuming the role of public transport organiser in such areas. Transport infrastructure is another important element affecting transport function. As a public good, its significance is related to the characteristics of infrastructure, which include: a long development period, high capital intensity, and typically a long period of return on capital investment. These features mean that private capital rarely engages in the development of transport infrastructure.

\section{Introduction}

The theoretical aspects of public goods are subject to public sector economics research. Public goods are provided by the public sector due to both social and environmental considerations. The primary suppliers of such goods are the central and/or local government, which does not necessarily mean that these entities produce such goods. In this case, the public is associated with consumption, rather than the production, of such goods. 
The social and environmental considerations result primarily from the failure of market mechanisms, which in turn results from the improper operation of such mechanisms. Such may be caused by low demand for the respective goods, among other factors.

The aim of this article is to present the features, types, and significance of public goods and to relate the theory of public goods to the transport sphere with particular consideration of transport infrastructure and transport services.

\section{Concept and types of public goods}

Economist Paul Samuelson formulated the concept of public goods in the 1950's. His work became the basis for the development of the theory of public goods, in which pure public goods were distinguished as the opposite of private goods (Samuelson, 1954). Public goods were recognised as those which serve an entire society and are characterized by egalitarian consumption.

Public goods were divided into pure public goods, common goods, and club goods. Pure public goods are characteristically non-rivalrous and non-excludable, which also results from high costs. The common goods, also referred to as common-pool resources, are also characteristically non-excludable; however, improper use of such goods results in their unavailability for others (for example, overfishing results in fewer fish being available in the future and overgrazing renders pasture land unusable). Examples of common goods are forests, pastures, water, and the atmosphere itself.

As Elinor Ostrom points out, it is important to determine the optimum usage of common goods (Ostrom, 1990, pp. 8-12). The Nobel prize winner showed that regardless a particular country's level of development (as divided into high, medium, and low development) the best solution is to entrust the management of common goods to local communities, thus rejecting the need for state interference (the nationalization of common goods) or their privatization.

Club goods, also referred to as social goods, are characteristically non-rivalrous and - in contrast to pure public goods - excludable. Due to their physical characteristics, these may be private goods (satisfying the individual needs of citizens and financed from private sources) or, primarily as a result of social policy, available, allocated, and financed (or co-financed) from public funds for a group of citizens as pure public goods. Examples include education, health care, and public transport.

Public goods are characterized by their physical indivisibility. This results in the inability to satisfy individual needs when accounting for consumer preferences. All users must adapt to the same standard (quality) of the available public good. In addition, high transaction costs limit excludability, yet simultaneous consumption does not cause any loss of performance, therefore associating such goods with zero marginal cost (Brol, 2010, p. 46). The cost curve for the production of pure public goods does not indicate variable cost.

In terms of characteristics, private goods are the opposite of public goods. Their purchase depends primarily on the financial capacity of the purchaser and on consumer purchasing preferences. Private goods may be consumed by one person (the purchaser) and therefore represent 'rivalrous' consumption.

\section{Classificetion of public yoods}

The classification of public goods is relatively difficult, even in the context of distinguishing their characteristic features. The following criteria re most commonly applied (Kwarciński, 2016, p. 26): 
- spatial - range of impact,

- social - public utility,

- economic - efficiency,

- financing - source of funding.

The territorial criterion makes it possible to distinguish public goods of local, regional, national, and global dimensions (Kaul, 2001, pp. 588-602). A smaller range of impact of public goods means greater restrictions on access to such goods by other people. Apart from the spatial approach, the range of impact may be determined by social status. An example may be public goods available only to selected groups of people, most often those of lower economic status.

When assessing the utility of public and private goods, it should be stated that public goods serve the general public and are therefore non-competitive, whereas private goods usually serve a narrow group of people (or in the extreme case one person), which results in competition for such goods. The utility of public goods is related with the activities of central and local governments and satisfaction of the collective needs of residents through the provision of public services, among other factors.

Services of public utility are an important element of the social security system and help to ensure social cohesion. Such services allow for the satisfaction of basic needs as necessary for the participation of residents in social and professional life, and are provided on a continual basis. They result from adopted social principles including solidarity and subsidiarity, thus making it possible to depart from the use of market mechanisms as the basic element controlling economic processes. The implementation of services of public utility may require restrictions on the freedom to provide such services on a commercial basis. Such restriction is predicated on the primary goal of public services, i.e. the most effective possible satisfaction of the needs of residents by the provision of access to public goods (EC Directive 2006/123).

Public goods are financed (or co-financed) from the public funds of central and/or local governments. As a result, collective consumption is financed externally, and the public good is available free of charge or for a small fee. This is a strictly theoretical approach. Public goods only appear to be free, and this may cause them to be misused or, in extreme cases, wasted.

Public and social goods (which may be private goods) are financed or co-financed from public funds (Owsiak, 2002, pp. 26-27). This assumption also means that social goods are excluded from the effects of market mechanisms. The rationale for the co-financing of such goods is social policy, which most often takes into account the need to protect vulnerable people who, due to lower income, may have limited access to some goods which are produced on a commercial basis.

The scope of provision of social goods depends on social policy and the public finances allocated for this purpose, the premise of which is to enable access to such goods. Without public support, either the use of social goods would be impossible or the scope of their provision would be much more limited, which is related to the allocation of resources on a commercial basis (Begg, 1997, p. 108).

Public goods are regulated by means of usage fees. These charges may be levied by central and/or local governments. One example is transport infrastructure, for which usage fees are charged. Usage fees may be considered as the fairest means of payment for the use of public goods, as they are based on the assumption that those who obtain greater benefits from such goods pay more (Stigliz, 2004, p. 152). 
There are no fees for the use of pure public goods, for which consumption by subsequent entities is associated with zero marginal cost of production (Samuelson, 2004, p. 509). This means that the cost of producing a good is not higher than the cost of providing it to one person. Examples of such goods are lighthouses, street lighting, and national defence. The use of public goods allows residents to save funds for the purchase of other goods, including private property.

The function of public goods is to ensure the ongoing and uninterrupted satisfaction of social needs in those areas which are important to residents. This situation applies to public services in whose production the market is not interested, or in such case as a portion of the population is limited in its ability to purchase such services due to price or location. Public goods serve to improve the functioning of the state, including the quality of life of residents, by limiting the consequences of the failure of market mechanisms.

\section{Transport as a public good}

Transport may be characterised as a public good through the prism of its functions, the basic of which are related to social and economic development. In the social sense, transport ensures territorial cohesion and, by providing mobility, determines standard of living by meeting the natural needs for movement and social satisfaction, and helping limit the phenomenon of social exclusion (Załoga, 2013, p. 43).

In the economic sense, transport is a necessary condition for satisfying social and economic needs, taking into account the spatial distribution of settlement and economic centres. Important is the positive direct and indirect impact of transport on economic growth and competitiveness, which pertains to the efficiency and effectiveness of management processes.

Transport also affects the process of environmental degradation. Further socio-economic development necessitates consideration of the reduction of the negative impact of transport on the natural environment, which is reflected in the internalisation of the external costs of transport, among other processes.

Problems related to proper social, economic and environmental development are included in the concept of sustainable development, in which transport plays a large role. Barbara Pawłowska points out the need to bring transportation under the umbrella of sustainable development using an appropriate set of tools and indicators to monitor and evaluate the concepts implemented (Pawłowska, 2013, p. 169).

\section{Transport infrrastructure as a public good}

When applying the theory of public goods to transport infrastructure, the leading role of government in the development and maintenance of such infrastructure should be emphasized. In this approach, the planning and financing of the construction and maintenance of infrastructure is of importance. Private capital is poorly suited to this important area of social and governmental function (except for a few specific examples). This may result from the long period of return on capital as well as uncertainty as to the profitability of the investment. In Poland, the national, voivodeship, county, and municipal governments are responsible for the development and maintenance of transport infrastructure, depending on the function of said infrastructure. The exception are cities with county rights that independently manage transport infrastructure regardless of the type of road. In other areas, responsibility is born by respective road managers, which results in varying road quality.

It is difficult to explicitly qualify transport infrastructure as any one of the categories of good distinguished in the theory of public goods. It may be considered as a public good, as a common good (a private good financed by 
central and/or local governments), or a private good (motorways). As roads are distinguished by limited capacity, they cannot be considered as pure public goods. Lack of usage fees for roads contributes to increasing congestion, which generates negative effects (decreased speed, wasted time) for all users of the good. This situation also causes higher external costs (noise, environmental pollution). The need to pay usage fees for motorways and express roads (for freight transport) allows these roads to be classified as private goods.

As a public good, transport infrastructure remains an important factor when choosing locations for economic activity or human settlement. It also provides territorial, social, and economic cohesion. Among the functions of transport infrastructure distinguished in the literature, the spatial, economic, and environmental aspects are subject to broader analysis.

Research conducted on the impact of transport infrastructure as a public good refers to:

a) time - the quantitative growth and qualitative development of transport infrastructure contributes to shortening travel times;

b) cost - transport infrastructure improves investment attractiveness and capital productivity and contributes to technical progress;

c) efficiency - impact on the transport process, and directly on the efficiency of both producers and household budgets (lower passenger car operating costs).

In the context of the theory of public goods, the following characteristics of transport infrastructure are particularly important: the slow rate of qualitative development, technical and economic indivisibility, the primary nature of infrastructure expenditure, spatial and functional immobility, the unsuitability of private and foreign capital in construction and development of infrastructure, and high capital density (Grzywacz, 1982). These features make necessitate the involvement of central and/or local governments in the organization (development plans) and financing of transport infrastructure.

The role of transport infrastructure should be related to such elements of the theory of public goods as nonexclusivity and non-rivalrousness. The lack of direct usage charges for transport infrastructure, with the exception of motorways and expressways, enables it to be considered as public goods sensu largo. Such infrastructure is generally available, with all users paying usage fees indirectly (i.e. via fees included in the price of fuel). Nonrivalrousness refers to the ability to use transport infrastructure at any time. Capacity presents some limitation to this approach.

In summary, transport infrastructure has a decisive impact on transport function. As a public good:

- it promotes development and economic growth,

- it improves social and economic cohesion across an entire country,

- it stimulates sparsely-developed areas,

- it stimulates peripheral regions,

- it affects the efficient movement of people and goods.

\section{Passenger transport services}

Passenger transport services serve to satisfy social and economic needs related to production and consumption as well as those resulting from the desire to use cultural goods or maintain social ties.

Considering the features of public goods, passenger transport services may be classified as social (club) goods. This means that transport services could be private goods, however due to both their function and the 
fact that they are publicly financed, they become social goods. The market for passenger transport services also includes transport services provided on a commercial basis (without subsidies), which can be considered as private goods.

Public mass transport services are connected with ongoing and uninterrupted satisfaction of the transport needs of residents. They perform many important social, economic and environmental functions, of which the primary include:

- providing access to products and services

- preventing social exclusion,

- reducing transport congestion,

- economic and functional stimulation of areas,

- ensuring a higher level of security,

- providing for better use of energy resources,

- reducing environmental pollution,

- providing for better use of space.

\section{Conclusion}

As the bodies responsible for defining the scope of public goods, the role of central and local government institutions is to determine the scope and means of delivery of such goods. This is based on ensuring ongoing and uninterrupted satisfaction of social needs in those areas which are important to residents and concerns public services in whose production the market is not interested, or in such case as a portion of the population is limited in its ability to purchase such services due to price or location. Public goods serve to improve the functioning of the state, including the quality of life of residents, by limiting the consequences of the failure of market mechanisms.

The significance of transport as a public good be characterised by its functions, the basic of which are related to social and economic development. In the social sense, transport ensures territorial cohesion and, by providing mobility, determines standard of living and helps limit the phenomenon of social exclusion In economic terms, this is an indispensable condition for satisfying transport needs, taking into account the spatial distribution of settlements. Further socio-economic development necessitates consideration of the reduction of the negative impact of transport on the natural environment, which is reflected in the internalisation of the external costs of transport, among other processes.

\section{References}

Begg, D., Fischer, S., Dornbusch, R. (1997). Ekonomia - mikroekonomia. Warszawa: PWE.

Brol, M. (ed.) (2010). Zarys ekonomii sektora publicznego. Wrocław: Uniwersytet Ekonomiczny we Wrocławiu.

Dyrektywa 2006/123 WE Parlamentu Europejskiego i Rady Unii Europejskiej z 12.12.2006 r. dotycząca usług na rynku wewnętrznym, Dz.Urz. UE L 376/36.

Grzywacz, W. (1982). Infrastruktura transportu. Warszawa: Wydawnictwa Komunikacji i Łączności.

Kaul, I. (2001). Global Public Goods: What Role for Civil Society? Nonprofit and Voluntary Sector Quarterly, 30 (3), 588-602.

Kwarciński, T. (2016). Dostępność publicznego transportu zbiorowego na obszarach wiejskich w Polsce. Szczecin: Wydawnictwo Naukowe Uniwersytetu Szczecińskiego.

Ostrom, E. (1990). Governing the Commons: The Evolution of Institutions for Collective Action. Cambridge: Cambridge University Press. 
Owsiak, S. (2002). Finanse publiczne. Teoria i praktyka. Warszawa: Wydawnictwo Naukowe PWN.

Pawłowska, B. (2013). Zrównoważony rozwój transportu na tle współczesnych procesów gospodarczych. Gdańsk: Wydawnictwo Uniwersytetu Gdańskiego.

Samuelson, P.A. (1954). The Pure Theory of Public Expenditure. Review of Economics and Statistics, 36 (4), 387-389.

Stiglitz, J.E. (2004). Ekonomia sektora publicznego. Warszawa: Wydawnictwo Naukowe PWN.

Załoga, E. (2013). Trendy w transporcie lądowym Unii Europejskiej. Szczecin: Wydawnictwo Naukowe Uniwersytetu Szczecińskiego.

Cite this article aS: Kwarciński, T. (2018). Transport as a public good. European Journal of Service Management, 3 (27/2), 229-235. DOI: 10.18276/ejsm.2018.27/2-28. 